\title{
PRETOS E PRETAS DE NAÇÃO: \\ tecendo vínculos e reconstruindo vidas na diáspora, Desterro, $1850 / 1880{ }^{1}$
}

Claudia Mortari Malavota ${ }^{2}$

Fábio Amorim Vieira ${ }^{3}$

Resumo: Este artigo busca evidenciar a presença das populações africanas, os chamados pretos de nação, na cidade do Desterro, na segunda metade do século XIX. A partir da pontuação de alguns de seus vínculos familiares e relações de trabalho, busca-se analisar os constantes processos de construção e reinvenção de suas identidades no contexto da diáspora. As fontes analisadas para tal abarcam notícias de jornais, ofícios criminais e cartoriais. As evidências apontam que os pretos e as pretas de nação ao desenvolverem seus trabalhos na cidade acabaram por estabelecer diversos vínculos de solidariedade, que indicam que criaram possibilidades de escolhas e lidaram com as incertezas de sua existência de uma forma que pode parecer ambígua, mas intrínsecas em suas vivências, dentro de um tempo e contexto de uma vila portuária ao Sul do Brasil.

Palavras-chave: Africanos, Vínculos Familiares, Identidades, Diáspora.

Abstract: This article demonstrates the presence of African people, the so-called Pretos de Nação, in the context of the city of Desterro in the second half of the nineteenth century. Through the analysis of their work and solidarity relations, this study aims to understand the properties of their identities. We assume that these properties go through constant reinvention and construction processes from established strategies for these subjects to survive in the context of diaspora. This study confronted historical sources such as newspaper reports, criminal and notarial offices. The evidence shows that these African men and women in order to develop its work in the city eventually established many ties of solidarity. It indicates that these people created opportunities of choices and dealt with the uncertainty of their existence in a way that may seem ambiguous, but intrinsic to their experiences within a context and time of a harbor town in southern Brazil.

Keywords: African, Family Linkages, Identity, Diaspora.

\footnotetext{
${ }^{1} \mathrm{O}$ presente artigo se constitui de resultados preliminares da pesquisa intitulada Homens e Mulheres de cor e qualidade: Um estudo acerca das identidades/identificações das populações de origem africana em Desterro/Florianópolis, 1870/1910, do Centro de Ciências Humanas e da Educação (FAED/UDESC). Desenvolvido desde agosto de 2011. O objetivo é mapear as configurações de identidades das populações de origem africana, através da análise de documentos que apontem suas relações de vínculo familiar e de trabalho a fim de perceber que estas passam por constantes processos de construção e reinvenção a partir de transformações no contexto estudado. A pesquisa contou com a participação das bolsistas de Iniciação Científica Mariana Heck Silva e Tamires Tavares Pacheco, ambas acadêmicas do curso de História da FAED/UDESC e também membros do Núcleo de Estudos Afro-Brasileiros (NEAB). Embora o recorte cronológico do trabalho seja a partir de 1870 para companhar algumas trajetórias de vida foi necessário recuarmos um pouco no tempo na pesquisa das fontes documentais.

${ }^{2}$ Professora Adjunta de História da África do Departamento de História do Centro de Ciências Humanas e da Educação (FAED/UDESC) e membro do Núcleo de Estudos Afro-Brasileiros (NEAB/UDESC).

${ }^{3}$ Acadêmico da $6^{a}$ fase do Curso de História do Centro de Ciências Humanas e da Educação (FAED/UDESC), bolsista de iniciação científica membro do Núcleo de Estudos Afro-Brasileiros (NEAB/UDESC).
} 
No dia vinte e um de novembro do ano de 1857, a crioula Eva, cativa do Doutor Manoel Pinto Portella, se dirige à Igreja Matriz para batizar a sua filha, a inocente Maria, então com apenas um mês de vida, a qual teve como padrinhos Egos, africano, e Nossa Senhora das Dores. ${ }^{4}$ Em outro momento, em vinte e dois de março de 1860, o Chefe de Polícia da Cidade de Nossa Senhora do Desterro, em correspondência enviada ao Presidente da Província de Santa Catarina, informa que foi preso na noite anterior o preto livre Francisco Sergio. Este foi encontrado perambulando pelas ruas da cidade a "1 hora da noite" e ainda fugiu da patrulha ${ }^{5}$, o que o tornou um suspeito em potencial. Cerca de um mês antes, em 10 de fevereiro, em situação diversa, o preto Joaquim Mina comprava a sua carta de alforria conquistando a sua tão almejada liberdade para que pudesse desfrutar desta "como se de ventre livre nascesse" e "onde lhe aprouver". 6

O que estes vestígios de histórias têm em comum?

Além de se constituírem de diversas experiências ${ }^{7}$ e vivências, o que é comum nestes fragmentos, ou vestígios, é a referência à procedência africana de seus protagonistas e a presença de indícios que apontam para a criação, por parte destes, de formas de viver a vida no contexto de uma vila portuária ao sul do Brasil do século XIX. São estes vestígios da presença africana na cidade do Desterro que este artigo pretende discutir e visibilizar.

Pretende-se mostrar que os africanos estabeleceram diversos vínculos de solidariedade e, também, de conflitos, lidando com as incertezas de sua existência de uma forma que pode parecer ambígua, mas intrínsecas em suas vivências, dentro de um tempo e um contexto. Mas algumas outras questões também podem ser problematizadas: como as populações de origem africana vão ser identificadas? Quais identidades vão ser construídas por estas na diáspora a partir de suas relações pessoais e vivências?

Para a construção de uma imagem possível do passado, nos dizeres de W. Benjamin (1985, p. 224), recorremos à pesquisa em diversas fontes documentais (ofícios de Delegados de Polícia, registros cartoriais, notícias de jornais, registros de batismo e processos de liberdade)

\footnotetext{
${ }^{4}$ ACMF (Arquivo da Cúria Metropolitana de Florianópolis). Livro de Registro de Batismo de Escravos da Freguesia do Desterro, 1857-1861.

${ }_{5}^{5}$ APESC (Arquivo Público do Estado de Santa Catarina). Livro de Correspondência do Chefe de Polícia ao Presidente de Província, mar. 1860, p. 136.

${ }^{6}$ CK (Cartório Kotzias). $1^{\circ}$ Oficio de Notas Livro 66, Desterro, 1859-1860, Fls. 27 e 27v.

$7 \mathrm{O}$ conceito de experiência aqui empregado se refere a uma forma de solução prática para analisar os comportamentos, os valores, as condutas, os costumes, enfim, as culturas (THOMPSON, 1988; WILLIAMS, 1979). De acordo com Challoub "a vigência do enredo da dominação paternalista não significava que os subordinados estavam passivos, incapazes de perseguir objetivos próprios, impossibilitados de afirmar a diferença. (...) afirmar a diferença no centro mesmo dos rituais da dominação senhorial”. (CHALLOUB, 1998).
} 
estabelecendo um diálogo com a bibliografia especializada que aborda a temática das populações africanas. O trabalho foi realizado através da análise qualitativa dos documentos, pois esta possibilita construir a história das múltiplas vivências e formas de estabelecimento de relações sociais de alguns indivíduos em particular (MALAVOTA, 2007). Aqui, muito influenciados pelas ideias de Ginzburg, pensamos que é preciso buscar nas fontes indícios, pistas, vestígios acerca das práticas sociais de uma pessoa, de um grupo de pessoas ou de uma família, analisá-las e interpretá-las (1989, p. 144-167). Isto porque, segundo Geertz, a cultura é uma teia de significados tecidas pelo próprio homem e como não temos "familiaridade com o universo imaginativo dentro do qual seus atos são marcos determinados" não podemos determinar que tal ato possui $x$ significado, não se dando, portanto, um significado real as práticas, mas interpretando-as (1989, p. 13-44).

Neste ponto de vista, as fontes históricas devem ser interrogadas e problematizadas. Mas a prova, obtida por meio da análise dessas fontes e usada pelo historiador para construção de um determinado conhecimento ou processo histórico deve ser vista apenas como uma perspectiva sobre a realidade, pois o ponto de vista da análise do historiador é seletivo e parcial. Além disso, é preciso considerar que a "forma como o historiador lida com as fontes, como elabora as interrogações acerca do seu objeto de estudo, como constrói a sua narrativa, de certa forma evidencia uma tomada de posição em relação àquilo que se propõe fazer". (MALAVOTA, 2007, p. 32-33). Portanto, as fontes não fornecem um acesso imediato a uma determinada realidade, nem são janelas através das quais é possível ver o passado tal como ele ocorreu, mesmo porque também são construções específicas de alguém de um determinado período.

Outra questão pertinente a ser considerada é pensar que as fontes de pesquisa que estamos utilizando são produções daqueles que detinham o poder evidenciando, sobretudo a forma como as elites brancas dirigentes pensavam no período com exceção feita aos processos judiciais dos quais se podem apreender, mesmo que indiretamente, os depoimentos de africanos e seus descendentes (WISSENBACH, 1998). Mas na perspectiva que estamos trabalhando pensamos que um olhar sobre os indícios nos permitem evidenciar não somente como a sociedade se estruturava ou as representações existentes sobre as populações africanas, mas principalmente como se identificavam e os laços de solidariedade que estabeleciam bem como as relações de conflitos que ocorriam.

Assim, a partir da problematização das fontes é preciso perceber, "não o que o poder público considerava a respeito destes indivíduos, mas principalmente os sentidos atribuídos por eles mesmos às dimensões de suas vidas a partir da construção de partículas de suas práticas cotidianas e das relações sociais" (MALAVOTA, 2007, p. 34). Através do rastreamento nas 
fontes dos nomes dos africanos e de seus donos, no caso de qualidade de cativos, tem-se o guia para a prática do mapeamento de relações homens e mulheres teciam entre si, construindo suas trajetórias históricas enquanto sujeitos ambientados no contexto da diáspora.

\section{A cidade e as populações de origem africana.}

O nosso contexto é a cidade do Desterro, capital da Província de Santa Catarina, localizada na Ilha do mesmo nome. Em seu coração, pulsava o porto, marcado pela presença de inúmeros trabalhadores das mais diversas origens, africanos e seus descendentes bem como brancos pobres. Estes sujeitos vertiam suor na beira dos barcos e navios diariamente, carregando diversos produtos e, entre eles, a farinha de mandioca produzida nos engenhos de várias freguesias da Ilha bem como em outras espalhadas ao longo do litoral catarinense como São Miguel, São José, Laguna e Tubarão. Era no porto do Desterro, que se reunia a produção e daí era embarcada para Montevidéu, Pernambuco e Rio de Janeiro (CARDOSO, 2008, p. 64). Na metade do século XIX de uma população de cerca de 11.000 habitantes cerca de 1.800 (16\%) desses estavam envolvidos nas atividades marítimas como mestres, contramestres, praticantes, patrões de lanchas, marinheiros, carpinteiros e calafates (HÜBENER, 1991, p.185).

Dados relativos ao ano de 1855 atentam para a importância dos portos no comércio da província. Segundo João José Coutinho, Presidente da Província, havia, no tráfico da capital e rios navegáveis, o emprego de 107 embarcações marítimas, algumas baleeiras e mais de 200 canoas pertencentes aos moradores do litoral. $\mathrm{Na}$ navegação costeira e de cabotagem eram 166 embarcações pertencentes à praça, tripuladas por 817 pessoas, sendo 428 brasileiros, 134 estrangeiros e 315 escravos. Mas, além dos dados relativos ao comércio marítimo local, há, também, a presença de embarcações estrangeiras no porto: uma de navegação feita para o Rio da Prata, outras duas do Rio de Janeiro, além de 3 embarcações estrangeiras. ${ }^{8}$

Também no âmago desterrense, estava a praça e a sua vivacidade era exaltada nos ruídos provocados por pessoas que por ali circulavam. Na beira da praia estavam as barraquinhas de comércio, ostentadas por africanos e crioulos, em meio a quitandeiras ${ }^{9}$ escravas ou libertas e passantes, indo ou voltando do porto. Alguns produtos também eram vendidos nas diversas

\footnotetext{
${ }^{8}$ APESC. Fala do Presidente da Província de Santa Catarina João José Coutinho, 1855.

9 As quitandas eram definidas à época como "casas em que principalmente se vendem verduras, frutas, carvão, lenha, ovos, e outras miudezas semelhantes, ainda que nelas também se vendam alguns gêneros comestíveis da terra, como farinha, arroz, milho, etc., por peso ou medida em pequena quantidade". Coleção das Decisões do Império do Brasil de 1844. Tomo VII. Rio de Janeiro: Reimpressa na Typografia Nacional, 1865, p. 44. Decisão 61 - Fazenda - Aviso de 31 de julho de 1844.
} 
canoas fundeadas ao longo da praia central da cidade, vindas de diferentes pontos da ilha e do continente, carregadas de gêneros que eram expostos em esteiras nas areias da praia. Próximo a este, o mercado da cidade era marcado pelo ir e vir de pessoas comprando, vendendo, conversando.

Esse espaço social, a vila portuária do Desterro, foi historicamente produzido de forma que [...] foi construído pelas pessoas que nele viviam ou que por ele apenas transitavam de passagem. Essas pessoas instituíram as suas marcas pelos espaços da vila continuamente, cotidianamente. Pertencentes a diferentes origens e condições sociais, tinham o cais do porto e as ruas da vila como lugares de trabalho, de sobrevivência, de vivência e de sociabilidade. (MALAVOTA, 2007, p.60)

Em Desterro, trabalhadores escravos e forros realizavam uma infinidade de ofícios urbanos: vendendo produtos nas ruas, carregando mercadorias no porto, construindo casas, trabalhando no serviço de ganho ${ }^{10}$ ou de aluguel, na iluminação pública, no transporte marítimo, como marinheiros e pescadores, em ofícios mecânicos ou na agricultura das pequenas propriedades existentes ao redor da cidade, bem como, exercendo uma infinidade de atividades domésticas (CABRAL, 1979).

Por exemplo, das rendas adquiridas pelas africanas e crioulas escravas e forras quitandeiras, que vendiam suas mercadorias em quitandas ou tabuleiros espalhadas pela cidade como citado anteriormente, dependia a subsistência de várias famílias, conforme nos informam os ofícios enviados à Câmara Municipal, nos quais algumas mulheres pedem a licença para suas escravas poderem vender produtos pela cidade. Segundo Pedro (1994, p. 126-127):

Em 1850, Angélica Maria da Conceição pedia, em ofício à Câmara, para ser liberada da licença que deveria pagar para uma 'preta vender doce pelas ruas desta cidade, para poder tirar o pão para si e seus inocentes filhinhos’. Informava, ainda, Angélica, que vivia na miséria, e que seu marido Manoel Francisco da Silva estava 'ausente'. Ainda em 1850, Ana Joaquina de Campos pagava licença para a 'preta Felipa' vender 'gêneros comestíveis e alimentares’. Maria Rita Conceição pagava licença para a escrava Maria

\footnotetext{
${ }^{10} \mathrm{O}$ trabalhador escravo nas áreas urbanas trabalhava junto ao seu proprietário era alugado ou trabalhava por conta própria, levando posteriormente uma parte da quantia que ganhava ao seu proprietário. Era o sistema de trabalho chamado de "ganho". A existência dos escravos de ganho é um dos exemplos que evidencia a variedade de atividades desenvolvidas pelos escravos e em contrapartida a complexidade das relações escravistas no contexto. Essa prática de trabalho permitia, em alguns casos, que o escravo ficasse como pagamento o valor que ultrapassava o "jornal" estipulado pelo seu senhor, possibilitando a acumulação de um pecúlio para a compra da sua alforria (SOARES, 1988).
} 
Calahá fazer o mesmo. (...) Ainda em 1850, de acordo com Pedro Ferreira da Silva, em suas Reminiscências, na Praça do Desterro, 'perto da praia, mulheres de cor preta frigiam peixe, cozinhavam mocotó e faziam comida para vender".

Em 1850, Francisco Antônio Cardoso, através de um requerimento à Câmara Municipal, pediu licença para que sua escrava, Maria, nação Angola, vendesse quitanda pelas ruas da cidade. No dia seguinte, enviou outro requerimento, em nome de sua mãe, Dona Marianna Joaquina do Livramento, para que suas duas escravas pudessem vender "gêneros de confeitaria pelas ruas e lugares" da cidade. ${ }^{11}$

Segundo Wissenbach, a experiência citadina dos escravos introduziu a todo o momento componente diversificado à sua condição. As suas ocupações funcionavam segundo às exigências dos mercados urbanos. "Acrescentando-se tais demandas ao menosprezo escravocrata reservado a todas as formas de trabalho manual, escravos e libertos, crioulos e negros africanos desempenhavam quase todas as funções das economias citadinas, das mais especificadas às menos qualificadas" (1998, p. 63).

Em meados do século XIX a cidade passava por transformações advindas do seu crescimento e a edificação de novíssimos prédios e reformas urbanas tornava a capital mais ancorada aos moldes metropolitanos a cada bloco cortado por Jeremias Lobo, filho do cativo Matheos $^{12}$, e outros trabalhadores da pedreira da cidade. Vestígios do processo de crescimento desta eclodiam, e a tinta era ainda vívida nos muros e nas paredes decoradamente pintados por conta da ilustre visita do Imperador Pedro II à Desterro em outubro de 1845 (CABRAL, 1979).

Esse crescimento pode ser percebido ainda através do número de edificações construídas. Em 1832, dentro dos seus limites, havia 29 quarteirões, sendo que a população contava com cinco mil pessoas. Já em 1866, havia 41 quarteirões, 852 prédios de moradia, além dos edifícios públicos. E em 1871, já havia na cidade 1542 edificações, das quais 151 eram sobrados, 31 assobradados e 1360 casas térreas. Estavam em construção o teatro, o quartel da polícia e o quartel das forças de depósitos (VEIGA, 1993, p. 78 e 80).

Contudo, não só os edifícios públicos, sobrados e chácaras pertencentes aos senhores e senhoras de alta e média estirpe habitavam a capital. Enraizadas nas outras faces da cidade, estavam às localidades pobres onde jaziam as choupanas e os cortiços ocupados por homens e mulheres de baixa renda, território das populações de origem africana, cativos e libertos. Diante

11 AHMF (Arquivo Histórico Municipal de Florianópolis). Fundo: Câmara Municipal de Desterro. Série: Requerimentos Diversos. Ano: 1849 a 1853. Pasta 12. Requerimento à Câmara Municipal, 27 de agosto de 1850 e Requerimento à Câmara Municipal, 28 de Agosto de 1850.

${ }^{12}$ APESC. Livro de Ofícios do Chefe de Polícia ao Presidente da Província, 1865 set. v. 06, p. 76. 
da presença cada vez mais constante destes cortiços, a elite desterrense via-se envolta por estas populações: lavadeiras, prostitutas, escravos, libertos (CABRAL, 1971). Sombras citadinas ambientadas em um grande labirinto urbano; populações brancas pobres e de origem africana que cresciam e, assim, faziam eclodir cada vez mais habitações populares na crescente Desterro:

A separação espacial entre classes sociais começou a se configurar na segunda metade do século XIX, quando as áreas residenciais da população de alta renda começaram a se concentrar nas primeiras quadras a oeste da Praça XV de Novembro. Esse afastamento físico se deu em um momento de proliferação dos cortiços, que se localizavam, predominantemente, a leste da praça, a partir da quarta quadra a oeste, nas margens do Rio da Bulha e nas encostas do maciço rochoso central. (SOUZA, 2010, p. 30)

Despertado o corpo onde residiam as populações africanas e afrodescendentes na cidade, este pode ser percebido em suas ramificações e divisões espaciais através dos documentos da época, como o estudo sobre salubridade de João Ribeiro de Almeida acerca de Desterro em 1863: “... nesta cidade 3 bairros de triste aparência, onde se acham reunidos todos os elementos de insalubridade. São os bairros da Toca, Pedreira (com os becos adjacentes à Tronqueira) e finalmente a famosa Figueira" (Apud SANTOS, 2009, p. 78). Esses espaços e suas populações eram alvos constantes da ação política de saúde pública e de controle policial na segunda metade do XIX e primeiras décadas do XX, pois se vinculou a população pobre com a doença, inserindo a questão no campo da "Segurança Pública". ${ }^{3}$

Mas, na nossa perspectiva, mais do que espaços vigiados eram lugares de estabelecimento de vivências, de sociabilidades, de sobrevivências e, também, de conflitos das populações de origem africana.

$\mathrm{Na}$ Toca, bairro localizado na encosta da montanha do Menino Deus, predominavam os pescadores e lavadeiras, homens e mulheres de origem africana, habitantes de numerosas casas de madeira com os quintais virados para o mar, caracterizando a relação destes sujeitos com as águas salgadas da cidade (SANTOS, 2009, p. 78-79). Presentes neste contexto, é possível nominar algumas pessoas: a preta forra Rita, o crioulo cativo Manoel, a parda cativa Maria, os cativos José, Catharina e Luiza, que nos primeiros meses de 1856 acabaram sendo vítimas de uma epidemia de cólera que acometeu e matou dezenas de pessoas e disseminou-se principalmente entre estas

\footnotetext{
${ }^{13}$ Sobre isso, ver o importante trabalho de ARAÚJO, Hermetes Reis de. A invenção do litoral. Reformas Urbanas e Reajustamento Social em Florianópolis na Primeira República. Dissertação de Mestrado em História pela Pontifícia Universidade Católica de São Paulo. PUC, 1989.
} 
populações, alcançando moradores de outros bairros. Temos também o Firmo, o Jacinto, a Laurinda e o Manoel, todos cativos e moradores da localidade chamada Menino Deus, vizinha à Toca, também assolados com a moléstia de 1856. Justina, crioula cativa e também assolada pela cólera era moradora da Figueira, ${ }^{14}$ território de marinheiros, estivadores e prostitutas, escravos trabalhadores da Marinha e capoeiristas. (SANTOS, 2009, p. 84-85)

$\mathrm{Na}$ Fonte Grande, povoação que agregava as localidades da Pedreira, Tronqueira, Campo do Manejo, Beco Irmão Joaquim e José Jacques estavam também inseridas as populações pobres e, em sua maioria, africanas da cidade.

\footnotetext{
"Na Tronqueira, viviam as lavadeiras da Fonte Grande, escravas libertas ou que tinham permissão para morar fora da casa de seu dono, soldados, que serviam no Quartel do Campo do Manejo, escravos libertos, trabalhadores braçais, prostitutas e os recémchegados à cidade, pobres que procuravam os cortiços” (SANTOS, 2009, p. 88 e 95).
}

A área atrás da Matriz, entre a Igreja de Nossa Senhora do Rosário e São Benedito dos Homens Pretos e a rua do Alecrim, eram locais com predominância de cortiços e casas ocupadas por pessoas de origem africana, como Genoveva, crioula forra, moradora na rua do Alecrim com seus três filhos, cuja casa ruiu sob estes em meados de $1859^{15}$, e Lídio, crioulo escravo, preso por ter tentado "forçar" uma preta perto da localidade da Igreja do Rosário, também em 1859 (SANTOS, 2009, p. 126).

Na Igreja do Rosário e em seus arredores a frequência africana e afrodescendente no século XIX mostrava-se ordinária, principalmente, em decorrência da existência das Irmandades de Nossa Senhora do Rosário e São Benedito dos Homens Pretos e a de Nossa Senhora do Parto. Estas, sediadas na referida igreja, eram compostas por homens e mulheres africanos e afrodescendentes, que circulavam nos seus arredores e no interior da Igreja em consequência das decisões e das relações que teciam entre seus irmãos e irmãs durante reuniões administrativas e celebrações referentes às suas confrarias.

Especificamente, a Irmandade do Rosário, capaz de expressar os desejos por legitimidade de uma parcela significativa de africanos, crioulos e pardos, se organizou principalmente em torno da comunidade de pretos da costa, leia-se africanos. Constituía-se enquanto um espaço estratégico para o estabelecimento de táticas de solidariedade entre os confrades que

\footnotetext{
${ }^{14}$ Todos os casos noticiados da cólera que se alastrou por Desterro nos primeiros meses do ano de 1856 encontram-se no APESC. Livro de Ofícios do Chefe de Polícia ao Presidente de Província 1856 - jan./mar. v. 01.

${ }^{15}$ APESC. Livro de Ofícios do Chefe de Polícia ao Presidente de Província 1859 mar./set. v. 01. p. 67
} 
possibilitavam à estes cuidar das crianças, socorrer os doentes e, principalmente, cultuar os seus mortos (MALAVOTA, 2011, p. 77-81).

Certamente, desde meados do século XVIII e ao longo de todo o século XIX, saía das portas da Igreja, no dia 25 de dezembro muitos dos pretos irmãos em comemoração à santa de devoção, Nossa Senhora do Rosário. Entre estes estaria, no ano de 1850, o irmão Francisco de Quadros ou Francisco Pombeiro, africano de nação Benguela, forro, vivenciando a procissão e a festa junto dos outros irmãos pretos da confraria, além de apadrinhados seus, também de origem africana, possivelmente presentes neste momento de grande importância às populações africanas desterrenses (MALAVOTA, 2007, p. 174).

A partir da década de 1840, os Códigos de Posturas proclamavam o controle através de uma ordem urbana hegemônica sob a população de africanos e afrodescendentes que passaram a serem proibidos de fazerem ajuntamentos regados a batuques e canções, preservando a ordem pública desejada pelas elites. O artigo 38 do Código de Posturas de 1845 é específico: "Ficão prohibidos d' aqui em diante, os ajuntamentos de escravos, ou libertos para formarem batuques; bem como os que tiverem por objectivos os supostos reinados africanos, que, por festas, costumão fazer." ${ }^{\text {16 }}$ Mas isto não quer dizer que esta prática tenha deixado de existir apesar e com a proibição (MALAVOTA, 2007, p. 38). Saltam aos olhos nos registros do delegado de polícia evidências de diversas práticas de africanos burlando os limites impostos. Alguns acabavam presos, a exemplo do preto Miguel, escravo de Caetano José da Costa, que foi preso por "infração de postura" no dia 15 de março de 1860. No dia seguinte do mesmo ano foi a vez do preto Manoel escravo de Antonio Marques "por andar fugido". Sorte melhor não teve o preto Antonio escravo de Alexandre Ignacio da Silveira, que foi preso no dia 17 "por correição". ${ }^{17}$

Por outro lado em outros casos os pretos livres e escravos tiveram melhor sorte. No dia 04 de junho de 1850, o Fiscal da Câmara, João Antônio Bueno, precisando cumprir as determinações das Posturas, enviou um guarda para pedir ao Comandante da Força Policial da cidade, mais alguns homens, para saírem em diligência. Não obtendo ajuda, o fiscal dirigiu-se para o lugar devido, localizado na rua da Trunqueira, onde estava ocorrendo um "Batuque". A casa que estava servindo como local de encontro pertencia a um "crioulo livre", Calisto Gomes, na frente da qual morava o Juiz Municipal Suplente que estava em exercício, o Comendador Leitão. Segundo consta, estavam reunidos no batuque "pretos livres e escravos", juntamente com os “cidadãos Manoel da Silva Teixeira, José Joaquim Ramos e Jezuíno Rabello da Silva”. O Fiscal da

\footnotetext{
${ }^{16}$ APESC. Desterro. Código de Posturas, Lei 222, 10 de maio de 1845.

${ }^{17}$ APESC. Livro de Ofícios do Chefe de Polícia ao Presidente de Província 1860 jan. mar, pg. 131.
} 
Câmara multou o dono da casa, conforme o Art. 44 do Código de Posturas, mas não conseguiu prender nenhum escravo, por falta de guardas (MALAVOTA, 2011, p. 49).

As tentativas de controlar os atos e os comportamentos dos africanos e afro-descendentes escravos e livres são indicativos dos receios e dos medos das elites "brancas". Como afirma Chalhoub (1988, p. 103), "as pessoas raramente têm coragem de admitir simplesmente que têm medo, recorrendo a argumentos lógicos e sofisticados para desqualificar e combater aquilo que é visceralmente temido".

Ao longo da narrativa construída de fragmentos de histórias emergem sujeitos denominados de várias maneiras: são pretos, pardos, crioulos, africanos, escravos, livres e libertos. O que estes termos pressupunham?

\section{Quem são os pretos de nação?}

Longe de pensar as populações de origem africana como um bloco homogêneo, cuja marca principal é a herança da escravidão pautada na insígnia da cor, da documentação pesquisada emergem indivíduos das mais diversas procedências e categorias sociais: crioulos, africanos de nação, pretos, pardos, escravos, forros, libertos e livres ${ }^{18}$. Essas expressões eram categorias utilizadas para classificar os africanos e seus descendentes e, na perspectiva que estamos trabalhando, acabaram sendo incorporadas por estes como um dos critérios de identidades. ${ }^{19}$

Conforme Mattos, dentre os critérios de diferenciação social era preponderante o da cor da pele. No entanto a noção de cor não designava um grupo racial ou níveis de mestiçagem, mas delimitava os lugares sociais, estando etnia e condição indissociavelmente ligadas. A cor era entendida como elemento de construção de uma identidade social que engendrava uma hierarquização refletida no cotidiano, nas várias instituições, na coletividade em geral. Segundo a autora, na região sudeste, durante a primeira metade do século XIX, o termo negro ou preto referia-

\footnotetext{
${ }^{18}$ Não é possível atribuir uma homogeneidade às populações de origem africana. O termo negro, no contexto do século XVIII e XIX, remetia a condição de escravo e como sinônimo de raça. No final do XIX e ao longo do século XX tal categoria vai acabar sendo incorporada, resignificada e recolocada se constituindo enquanto um conceito político nascido entre os afro-americanos e estudantes africanos, que tinham como objetivo estabelecer uma solidariedade racial entre os negros. Assim, tal ideia foi incorporada pelo Movimento Pan-Africanista, na diáspora, objetivando dar um caráter de luta política e de solidariedade na luta dos negros contra a discriminação. Em África, tal movimento de solidariedade foi um dos responsáveis pela luta por libertação do domínio colonial (HERNANDEZ, 2005; APPIAH, 1997).

${ }^{19}$ Nesta perspectiva, Malavota (2007) a partir do estudo da configuração dos vínculos parentais estabelecidos entre as populações de origem africana, em Desterro na primeira metade do XIX, acabou por evidenciar a multiplicidade de sujeitos e arranjos familiares e de solidariedade. Para, além disso, influenciada pelas referências teóricas de Hall, Gilroy e Bhabha, acabou por discutir e apontar o processo de configuração de identidades dos africanos na diáspora.
} 
se à condição escrava, atual ou passada (forro). A qualificação de pardos é a que possuía uma maior especificidade. Os pardos eram duplamente qualificados como cativos, forros ou livres. Para os homens livres, o termo pardo era atribuído ao não branco. Por isso a importância de ser classificado nos processos como brancos, pois era indicativo de liberdade. Na segunda metade do século, entretanto, a referência à cor branca desaparece, e o critério cor continuará a ser usado apenas para se referir a um recém - liberto, marcando, portanto, a condição cativa do sujeito e sua descendência (MATTOS, 1998, p. 96-98). No caso específico dos termos crioulo e nação, o primeiro referia-se ao descendente de africano já nascido no Brasil e o segundo aos africanos de diversas regiões de procedência em África. Importante considerar que tais características têm sido identificadas nas fontes documentais que estamos utilizando para o contexto da segunda metade do XIX. Especificamente o que nos interessa pensar e discutir é em relação ao termo nação e a questão da redefinição das identidades dos africanos.

A ideia de reinvenção das identidades está relacionada à perspectiva dos estudos acerca do mundo atlântico, da diáspora, dos processos inter e transculturais de construção das identidades que apontam que o processo global de formação de sociedades multiculturais, constituídas por diferentes grupos étnicos e culturais, que iniciou-se com a expansão e conquistas europeias. Para Gilroy (2001) as culturas e as identidades formadas no Novo Mundo são indissociáveis da experiência da escravidão, dos fluxos e das trocas culturais através do Atlântico. As experiências do desenraizamento, do deslocamento e da inserção dos africanos num novo contexto resultaram num processo de reinvenção das identidades e das culturas. Nesta perspectiva, o próprio conceito de diáspora não possui a ideia de dispersão que carrega consigo a promessa de retorno redentor. Ela representa um processo de redefinição cultural e histórica do pertencimento, implica, para além do deslocamento, mudança, transformação. As identidades, no contexto da diáspora, tornam-se múltiplas, de forma que, junto ao elo que liga o sujeito a sua terra de origem, outras identificações são criadas; portanto a identidade não é fixa e resulta da formação de histórias específicas podendo se constituir como um posicionamento em relação a um dado contexto. Algo que Hall (2003) denomina de conjunto de posições de identidade: dependem da pessoa, do momento e do contexto.

Nesta perspectiva as escolhas identitárias são mais políticas que antropológicas, mais associativas, menos designadas. É uma situação ambígua e uma questão histórica; portanto “[...] cada uma dessas histórias de identidade está inscrita nas posições que assumimos e com as quais nos identificamos" (HALL, 2003, p. 34 e 433). Portanto, as identidades criadas ou reinventadas na diáspora não podem ser tomadas como resultado de uma assimilação completa, pois representam novas configurações marcadas pelo processo de transculturação, que, por sua vez, não ocorre de mão única: a construção ou reinvenção de identidades ou da diferença é dialógica e 
não binária, embora, muitas vezes, o equilíbrio seja desigual, pois são inscritas nas relações de poder, dependência e subordinação, características do colonialismo. (HALL, 2003, p. 67)

Nesse sentido, é preciso pensar na produção e na circulação transnacional de ideias, mas também na dinâmica da leitura e da tradução por meio das quais essas são incorporadas e ressignificadas a partir das especificidades históricas e culturais de cada sociedade (HANNERZ, 1997, p. 121-122). Tal abordagem é extremamente importante porque considera a mútua, embora desigual, influência das diferentes culturas, sem, contudo, reduzir a história das populações de origem africana apenas à sua vitimização.

É a partir dos pressupostos colocados anteriormente que, entendemos, deve ser compreendidos o processo de escravização dos africanos e de reinvenção das suas identidades. Descobrir, analisar e discutir a multiplicidade de experiências dos africanos escravos e libertos possibilita compreender as características históricas de Santa Catarina. Permite também abranger a complexidade dos arranjos de convivência, das relações entre cor, condição social, região de procedência e lugar na sociedade do período.

Para isso, é imperativo considerar que o próprio termo África e, conseqüentemente, africano são uma construção moderna, referindo-se a uma multiplicidade de povos, com línguas e culturas diversas, cujo ponto de origem comum está no tráfico de escravos e na escravidão como condição jurídica. Ambos foram “[...] forjados na fornalha do panelão colonial” (HALL, 2003, p. 40).

O processo de construção de novas identidades iniciava-se ou nas feitorias na África, do outro lado do Atlântico, ou na chegada aos portos brasileiros quando estes passavam a ser designados, pela sociedade escravista brasileira, pela terminologia "de nação" que se referia ou a portos de embarque, a região de onde eram provenientes ou a uma identificação dada pelos próprios traficantes em razão de algumas semelhanças atribuídas pelos europeus (SOARES, 1998). Portanto, o termo acabava por aglutinar sujeitos pertencentes a diferentes grupos étnicos e se refere a regiões de procedência.

Em pesquisa realizada, para o período entre 1788 a 1850, nos livros de batismo da Freguesia de Nossa Senhora do Desterro, foram identificados e sistematizados 5.245 registros de batismos de escravos. ${ }^{20}$ Destes, $1.138(22 \%)$ eram de adultos africanos e apresentavam como referência a procedência africana, ${ }^{21}$ sendo as mais significativas: congo (267), cabinda (259),

\footnotetext{
${ }^{20} \mathrm{Na}$ pesquisa por ora em andamento, tem-se realizado a sistematização dos registros de batismo para a segunda metade do século XIX, incluindo os livros de escravos e livres.

${ }^{21}$ Foi no contexto da segunda década do século XIX que ocorreu um maior número de batismos de africanos adultos e, portanto, uma intensificação do tráfico na cidade. Dos 1.138 africanos batizados, 626 tinham entre 15 e 49 anos, 211 entre 4 e 14 anos e apenas 3 deles tinham a idade de 50 anos. Em 296 registros não foi referida a
} 
moçambique (197), costa (171), monjolo (59) e mina (55). Ou seja, havia a predominância de indivíduos, principalmente da região da África Central Atlântica, seguido pela África Oriental e em menor presença da África Ocidental. Por sua vez, a procedência dos pais e mães africanos (famílias nucleares) nos registros também acompanhou a tendência para os recém-chegados: em maior número está congo, angola, benguela, rebolo, monjolo, destacando-se a procedência guiné (18 vezes). Especificamente este termo era utilizado na metade do século XVIII para se referir à região do Congo e de Angola na África Central Atlântica e cai em desuso ao longo deste mesmo século sendo possível supor que, uma mãe de procedência da guiné já estava inserida no contexto da vila na segunda metade do século XVIII. Em relação as denominações das procedências ou nações das mães africanas (famílias matrifocais) foi possível identificar as seguintes regiões de procedência: 37 da África Oriental (Moçambique); 83 da África Ocidental (guiné, calabar, mina, nagô); 759 da África Central Atlântica. Mas o maior conjunto destas, 800 ao total, é formado por aquelas com denominações de procedência gerais (costa, nação, nação africana, africana de nação, África, costa da África) que podem ser referentes a toda a costa da África Ocidental e Central (MALAVOTA, 2007, p. 89-90; 111-12; 124-127). ${ }^{22}$

No entanto, é possível que no processo de construção de novas identidades esses nomes de nação, embora atribuídos aos africanos, podem ter sido assumidos por eles próprios no processo de reorientação dos critérios de identidade (MALAVOTA, 2007). Essa é a abordagem realizada por Oliveira (1995) em seu estudo, para a qual o termo nação foi utilizado como ponto de partida pelos africanos para a elaboração de novas identificações. Por esta razão, de acordo com Soares $^{23}$ (1998), ao invés de discutir as procedências das populações africanas do ponto de vista de buscar uma reconstituição de uma cultura original, é importante identificar os grupos de procedência organizados na sociedade escravista:

[...] a noção de grupos de procedência privilegia as formas de organização dos indivíduos em novos grupos, nos locais onde eles se estabelecem (seja nas fazendas, nas lavras ou no trabalho urbano, por exemplo). [...] O grupo de procedência se constitui na relação entre o escravo e a sociedade escravista. Se, por um lado, os livros paroquiais se apropriam de categorias próprias aos grupos étnicos africanos e ao universo da

idade do batizando e em 6 o registro encontrava-se ilegível. Desses dados observa-se que havia um predomínio de africanos adultos (MALAVOTA, 2007, p. 90-92).

22 Ao longo dos registros, além dos termos já conhecidos que se referem a portos de embarque ou regiões na África, algumas procedências são bastante genéricas, no caso, África, Africana, Africano de Nação, Costa, Nação, Nação Africana.

${ }^{23}$ Essa ideia está presente nos estudos de Soares (1997 e 2000). A categoria de análise - "grupos de procedência" - criada pela autora, influenciou vários outros trabalhos. Ver, por exemplo: SOUZA, 2002; FARIAS, SOARES, GOMES, 2005. 
geografia do tráfico para classificar os grupos de procedência, por outro lado, os grupos se apropriam dessa nova identificação para se organizar (Soares, 1998, p. 10).

Portanto, o apresamento em África, a travessia do Atlântico, o desenraizamento, a inserção não menos violenta num novo contexto, a luta cotidiana para viver e sobreviver marcaram a experiência e as vivências de africanos, sobretudo pela condição de estrangeiros e de cativos. Tal processo vai desencadear a reinvenção das identidades, a redefinição cultural e histórica do pertencimento. Neste sentido, junto ao elo entre o sujeito e a sua terra de origem outras identificações são criadas constantemente a partir de contextos históricos, de situações específicas de tomada de posicionamento e de escolhas (MALAVOTA, 2007).

Essa abordagem, sem dúvida, nos parece essencial para se pensar e compreender os arranjos de solidariedade, as escolhas dos parceiros, os vínculos de compadrio e, porque não, os conflitos e as diferenças estabelecidas entre as populações de origem africana.

\section{Tecendo vínculos e reconstruindo vidas na diáspora}

$\mathrm{Na}$ segunda metade do século XIX, é possível identificar, nas fontes pesquisadas, vestígios das relações estabelecidas entre as populações africanas na cidade do Desterro que evidenciam as tomadas de posição em relação ao contexto que estavam inseridos: fizeram escolhas, lidaram com as incertezas do cotidiano e com as hierarquias de poder estabelecidas, construíram vínculos de proteção e ajuda mútua.

Evidentemente, quando se trabalha com a história dessas populações é preciso um trabalho minucioso e nem sempre frutífero de busca de informações. Algumas histórias que conseguimos percorrer a partir da pesquisa numa infinidade de fontes se constituem apenas fragmentos, mas que permitem evidenciar as vivências e as existências. Particularmente, isso é importante no que diz respeito ao contexto que estamos pesquisando: uma cidade portuária ao Sul do Brasil. Esta região divulgada pelos meios de comunicação como "um pedacinho da Europa" teve, durante muito tempo, uma historiografia que acabou por invisibilizar a presença das populações de origem africana sob o argumento das especificidades da ocupação histórica do sul do Brasil (MALAVOTA, 2007). Evidentemente, vários estudos, principalmente a partir da década de 90 vêm demonstrando os equívocos desse discurso. Para além de quantificar, os novos 
estudos tem procurado também visibilizar as experiências históricas dessas populações. ${ }^{24}$ Vamos a algumas dessas evidências.

Ainda que classificadas pela insígnia da escravidão, as populações africanas, no contexto de Desterro no século XIX, possuíam vínculos e correlações com muitos dos habitantes da vila não possuidores das qualidades de africano, crioulo, cativo ou liberto. Tais sujeitos conviviam entre si diariamente na cidade e suas circulações garantiam solidariedades, afinidades e conflitos. A procura por serviços fornecidos por africanos pautava relações que muitas vezes sobrepunham questões de troca de trabalho e interesses por aspectos inerentes às populações africanas afloravam entre homens e mulheres brancos.

Manoel Vieira, em janeiro de 1861, contratou os serviços dos pretos libertos Joaquim Silveira e Joaquim Venâncio para que estes assassinassem sua esposa e filha com o uso de feitiços, tidos a época como o conhecimento e uso de ervas e substâncias venenosas pelos oriundos do continente africano. Tais práticas apresentam-se tão a par de homens como Manoel Vieira, que, segundo o depoimento de Joaquim Venâncio no ofício criminal, Manoel havia entregado a Joaquim Venâncio um pedaço seco de umbigo de criança, com o que este deveria executar o feitiço para matar a mulher e a filha daquele. Também convidativo a se pensar certas práticas africanas no contexto desterrense está o depoimento do outro Joaquim, Silveira, que afirma ter sido abordado por Manoel Vieira para que fizesse o feitiço, recusando-o, pois só sabia "benzer". Além do emprego de plantas e substâncias tóxicas, têm-se as experiências sociais presentes em um contexto cuja presença africana dá-se além das práticas de trabalho, mas cujas outras atividades e conhecimentos são também explorados por uma sociedade envolta a homens e mulheres africanos e portadores de cultura resignificada no meio diaspórico da heterogeneidade. ${ }^{25}$

Os ecos da presença de sujeitos como Joaquim Venâncio perpassam relatos presentes nas mais diversas documentações. No rastro de suas experiências registradas documentalmente, constrói-se uma imagem possível do passado com homens e mulheres presentes nominalmente e experiencialmente em registros batismais, matrimoniais, inventariais. Documentos que atestem vínculos qualitativos e construtores de teias relacionais, reflexos de rastros de vivências destes sujeitos de origem africana em Desterro. "Pistas documentais". Além de mencionado no ofício policial referente ao feitiço para assassinar a esposa e a filha de Manoel Vieira, atestando-o enquanto conhecedor de tais práticas mágicas, Joaquim Venâncio aparece em outras documentações da época, batizando seu filho Venâncio no inverno de 1816 junto da esposa Joanna, também africana (MALAVOTA, 2007, p. 98); no batismo do afilhado Clemente, em

\footnotetext{
${ }^{24}$ Sobre esta questão (CARDOSO, 2010; MALAVOTA, 2011; MAMIGONIAN, 2006).

${ }^{25}$ APESC. Livro de Ofícios do Chefe de Polícia ao Presidente de Província 1861 - jan./mar.
} 
1817, onde ele e sua esposa aparecem como de nações Angola e Benguela, respectivamente. Quando batizam a filha Cecília, em 1821, estes se apresentam como pretos da costa (MALAVOTA, 2007, p. 118)

Corolário ao trânsito atlântico está um vislumbre da vida de Agostinho Maria Leopoldina, cujo inventário datado de maio do ano de 1881 abre-nos a possibilidade de conhecer as relações tecidas por este preto mina liberto na vila portuária desterrense. Morador em um dos cômodos do cortiço Cidade Nova, Agostinho, que devia alguns meses de aluguel ao dono da propriedade que habitava, falece em 1881. Sem herdeiros, coube, segundo a documentação, a outro preto mina, Diogo Luz, devedor seu, que preparasse seu funeral. ${ }^{26}$

É possível pensar que em uma vila oitocentista no contexto das práticas escravistas, a presença africana, ainda que imposta à hegemonia social europeizada e cristã, praticava (re)elaborações culturais de modo a fazer vivos aspectos oriundos do solo africano. Suas reinvenções pautavam-se na sincronia com eventos e práticas católicas, de modo que estes exerceriam, muitas vezes à sua peculiar maneira, ritos de procissão e cerimônias fúnebres. Estas últimas de suma importância para as sociedades africanas, onde a morte colocava-se enquanto rito de passagem, transcendência para um outro mundo, fator essencial para a elaboração do ancestral, figura residente entre os homens e a divindades supremas de cada cultura. Ansiar ter uma cerimônia mortuária carregava consigo, para as populações africanas, elevar-se à ancestralidade, emanando através dos cultos póstumos e da descendência a herança digna de uma existência terrena plena (LEITE, 1982 apud MALAVOTA, 2011, p. 101-103 e MATTOS, 2011, p. 158-159).

À Diogo Luz coube a função de preparar o funeral de Agostinho Maria Leopoldina. Experiência possivelmente repleta de significados para os dois sujeitos, africanos. Juntos das cerimônias realizadas pela Irmandade do Rosário e São Benedito, Agostinho e Diogo estavam inseridos em um conjunto de práticas sociais, onde suas reinvenções ora se prestavam como forma de exercerem práticas caras a eles, ora voltavam seus aspectos reinventados à sociedade que enxergava estes resquícios africanos nas práticas e hábitos exercidos por estes sujeitos no contexto da cidade. Interessante neste sentido é o trabalho de Regiane Mattos que nos apresenta o relato de Leonardo Arroyo referente aos ritos fúnebres realizados pelos africanos da irmandade de Nossa Senhora do Rosário em São Paulo no século XIX, cuja tolerância da igreja incomodava os novos moradores do largo do Rosário, que se sentiam perturbados com a cantoria dos membros da irmandade nos ritos fúnebres realizados durante a noite (ARROYO, 1954 apud MATTOOS, 2011, p. 160). Além das considerações dos moradores próximos à irmandade, têm-se

\footnotetext{
${ }^{26}$ AFF (Arquivo do Fórum de Florianópolis). $1^{\text {aa }}$ Vara da Família- caixa 021881 nº . 50/64.
} 
a evidência documental de um costume diaspórico, praticado por sujeitos africanos em ambiente brasileiro oitocentista. O incômodo com a música entoada pelos irmãos em cerimônia mortuária nos possibilita supor a existência de uma fagulha cultural africana a ser exercida sobre o costume do enterro. Tais sujeitos diaspóricos têm suas experiências como pontos de partida para a possibilidade de se pensar os homens e mulheres vindos da África presentes na vila de Desterro, sob os olhos de uma sociedade hegemônica à hábitos que fugissem aos moldes europeus e católicos de posturas sociais.

Também significativo às experiências construídas pelas populações africanas encontra-se Francisco de Quadros, abordado por Malavota (2007, p. 174). Seu matiz experiencial torna-se passível de ser observado por meio da documentação analisada pela autora, onde se podem considerar importantes informações registradas de Francisco, também conhecido como Pombeiro por seu ofício na quitanda. De nação Benguela e condição forra, Francisco de Quadros figurava nas ruas desterrenses, em meados do século XIX, com seu chapéu de pele, sobrecasaca e colete, circulando nas vielas da cidade, entrando e saindo da Igreja de Nossa Senhora do Rosário e São Benedito dos Homens Pretos, exercendo seu ofício de quitandeiro na vila ou plantando seus tipos de lavoura. Membro da Irmandade do Rosário, participando das reuniões enquanto irmão ocupante do cargo de juiz, o qual ocupou três vezes enquanto homem preto e africano, apadrinhou vários africanos recém-chegados, batizou filhos de africanas, estabeleceu vínculos familiares com uma mulher crioula, possuiu duas cativas.

Através de suas experiências sociais, marcas deixadas na senda documental, é possível perceber a pluralidade de identidades vestidas e reelaboradas por Francisco: benguela, preto forro, pombeiro. Remetem a uma origem africana, a uma experiência na escravidão na diáspora e ao exercício de um trabalho por ele exercido em Desterro. Também passível de análise referente às suas vivências enquanto sujeito diaspórico está a documentação referente à sua morte. Falecido em 1853, teve seu funeral sob os cuidados de outro africano, Feliciano dos Passos. Quatro anos depois da morte, os membros da Irmandade ainda mandavam rezar missas em sua memória. Uma vida também pontuada pelas relações fiadas através de vínculos sociais modeladores da identidade de Francisco, esta presente em um contexto espacial e temporal de adaptabilidades e transformações múltiplas. Tal vivência pode ser compreendida também por aquilo que a historiografia social mais recente sobre a escravidão, nas sociedades citadinas, tem apontado para a tendência de determinadas categorias de trabalhadores (escravos, libertos e livres pobres) para a aglutinação. Como coloca Wissenbach (1998, p. 73-74), 
De perspectivas diversas, os escravos aparentavam-se com os libertos e ambos aproximavam-se dos brancos remediados. Sem eliminar condições sócio jurídicas diferenciadas e distintas entre si, mas revelando elementos de aderência e continuidade entre as formas sociais, tal conformação remeteu-se aos padrões formais e informais da organização social e do trabalho nas cidades e, nesse sentido à convivência verificada nos mercados citadinos entre livres e escravos.

A partir da análise do pecúlio de Manoel, pardo, negociado entre os anos de 1882 e $1883^{27}$, têm-se a oportunidade de contemplar caso bem interessante. Diante dos documentos do século XIX referente às práticas de africanos e seus descendentes na vila de Desterro, têm-se presentes, como aponta Malavota, construções de identidades através de vínculos afetivos e de compadrio (2007, p. 168-169). Apadrinhar filhos de africanas ou até mesmo financiar suas cartas de alforria enquadra-se nestas práticas como a experiência ocorrida com Manoel, presente na documentação.

Em 1882 a preta liberta Maria Mina da Costa, que se identifica como tia de Manoel, homem pardo e pertencente ao cel. José Feliciano Alves de Brito, negocia com este a compra da liberdade do sobrinho. Neste sentido, se compromete a pagar ao senhor a quantia de $900 \$ 000$ réis, no prazo de um ano, ficando seu sobrinho livre no momento da assinatura do referido acordo. No entanto, ao final do período de um ano Manoel encontrava-se, no mês de setembro de 1883, retido em um depósito para ser vendido no Rio de Janeiro por seu senhor. O que aparece na documentação é que ficou faltando à Maria pagar 407\$000 réis. No entanto, no mesmo mês Manoel e seu advogado pedem para que seja depositada, em juízo, a quantia de $493 \$ 000$ réis como pecúlio para compra de sua liberdade quantia essa proveniente de uma doação recebida de sua suposta tia. Porém, o cel. José Feliciano Alves de Brito alega que a negociação é inválida, pois, segundo ele, o pecúlio ${ }^{28}$ de Manoel é inexistente, acusando Maria de planejar enganá-lo, além de apontar possíveis irregularidades no negócio, afirmando que esta enquanto africana e Manoel oriundo de outra cidade, não poderiam possuir vínculos de parentesco consanguíneo entre ambos e, consequentemente, a negociação de sua alforria por ela. E mais, acusa que a liberta Maria Mina e Manoel, moravam juntos e estavam agindo de má fé para que esta não pagasse os $407 \$ 000$ que ficou a dever. O Coronel afirma que Manoel estava servindo e pagando jornais a Maria Mina, e que sendo robusto, se empregava no porto da cidade e conseguia facilmente, empregando-se no "serviço marítimo", a quantia de $40 \$ 000$ a $100 \$ 000$ mensais.

\footnotetext{
${ }^{27}$ AFF. $1^{\text {a }}$ Vara da Família. Caixa 02 -1883 n. 199.

${ }^{28}$ O Processo de Pecúlio (nomenclatura da época) consiste em um pedido feito pelo escravo em nome de seu advogado ou procurador para que o Juizado de Órfãos e Ausentes mandasse depositar nos cofres públicos as economias do cativo com o fim de serem utilizadas posteriormente para obtenção de sua liberdade.
} 
Vendo a possibilidade de partida de Manoel a outro contexto e o desligamento de Desterro e de todas as teias afetivas a ele atadas, Maria Mina da Costa, africana liberta, intervém juntamente com Manoel no sentido de adquirir a tão almejada liberdade.

É possível apreender de tal documento inúmeros vestígios sobre as relações de trabalho e vínculos entre os dois sujeitos.

O primeiro que nos interessa especificamente refere-se à questão do estabelecimento dos vínculos familiares e de afetividade entre Manoel e Maria. Analisando a trama tecida e registrada no pecúlio de Manoel, abre-se a possibilidade de perceber os laços feitos e desfeitos na vida deste rapaz de 24 anos. Sem dúvida, compôs vínculos afetivos com Maria, sendo esta tia de Manoel ou não, atestados através da intervenção desta na sua negociação de liberdade. Sendo esta africana e assumindo caráter de sua parenta, observa-se aí o uso de identidade elaborada e, a partir disto, a ação impulsionada pelas relações de afeto ou compadrio existidas por estes homens e mulheres heterogêneos. Seu senhor, o cel. Brito, por sua vez, pode ter suas ações referentes a Manoel observadas e passíveis de interpretação. Se nos começos da documentação este aceitava a negociação com Maria, no ano de 1883 seus interesses voltaram-se contra o acordo da alforria de Manoel, alegando ser seu pecúlio nulo. Estratégia de Maria para impedir a venda imediata de Manoel ao Rio de Janeiro ou astúcia por parte de Brito para arrecadar o dinheiro das parcelas e ainda ter seu cativo de volta? Nossa interpretação do caso coloca os interesses dos sujeitos da questão como múltiplos nós em uma rede, fiados e desfiados no espaço entre 1882 e 1883. Manoel está no centro dela, é o coração de onde saem e entram todas as veias e artérias pulsantes, bombeando vivências e recebendo experiências, compondo a sua vida e as interdependências inerentes a ela.

O segundo vestígio da documentação se refere a questão da possibilidade que os cativos urbanos possuíam de gerar recursos para si através do trabalho ao ganho, fato que tem sido sistematicamente apontado pela historiografia. Este sistema de trabalho facilitava o acúmulo do pecúlio e muitas vezes o trabalhador cativo possuía mais autonomia do que o assalariado, na medida em que podia escolher onde trabalhar e em qual horário, contanto que no fim do período combinado (geralmente uma semana) entregasse o jornal para seu senhor. (MATTOS, 1998; CHALHOUB, 1990).

Esse tipo de prática só era possível através de uma ampla gama de negociações entre cativos e seus senhores e a historiografia têm apontado que os primeiros eram exímios negociadores. Mas a negociações não eram específicas de uma forma de trabalho, sendo comum encontrar cativas empregadas no serviço doméstico que acumularam pecúlio, o que pode ser 
atribuído às estratégias familiares para a compra da alforria. (CHALHOUB, 1990; MENDONÇA, 1999; PENA, 1988; XAVIER, 1996; REIS, 1988).

Este pode ser o caso de Francisco de Siqueira e Catharina. Ela, de nação Benguela, na condição de cativa, é comprada de seu antigo senhor por ele, Francisco de Siqueira, preto forro, que posteriormente lhe concede a liberdade 8 anos depois de objetivá-la (MALAVOTA, 2007, p. 74). Atentando a outras documentações onde as existências de Catharina e Francisco ecoam, percebemos nos registros de batismo seus nomes, onde é possível descobrir que ambos, e principalmente Francisco, apadrinharam muitas crianças filhas de africanas, atestando as ligações de compadrio destes sujeitos. Catharina tem sua identidade reinventada no contexto desterrense: fora cativa, depois comprada sob esta condição por um africano liberto, por quem consegue alforria, e, posteriormente, conforme os dados apontam, como companheira e madrinha junto de Francisco de Siqueira (MALAVOTA, 2007, p. 167-168).

No contexto de meados do século XIX, as referências a procedência ou a cor dos registros de batismo vão rareando, tornando mais difícil identificar os vínculos parentais estabelecidos pelas populações de origem africana em Desterro, a exemplo de dois especificamente escolhidos como evidência para o escopo deste artigo. No dia dois de Março de $1851{ }^{29}$ quatro pessoas cortavam o campo que separava a Igreja Matriz do Desterro da praia: a crioula livre Inocência Maria de Nazaré, seu marido Libeno José de Paula, pardo livre, e seus dois filhos, José e Eliseu, de apenas quatro meses de vida. Na Igreja, o Vigário Antônio João Muniz realizou a cerimônia do sacramento de batismo que tiveram como padrinhos o senhor José de Serra e a senhora Genovevia Maria de Serra. As crianças tinham como avós paternos o senhor Ignácio Antônio Albino Manoel e a senhora Maria Joaquina de Nazarett. Em outubro do mesmo ano, ${ }^{30}$ Matildes Maria Luiza e Francisco Manoel Antônio, ambos crioulos livres, batizaram o pequeno Francisco, cujos padrinhos foram Francisco Pereira Fernandes e Carlota Constança d'e Aguiar Fernandes. No registro ainda constavam o nome dos avós paternos Manoel Antônio e Ellena Rosa, e os maternos Felippe Nery e Luiza Maria da Conceição.

\section{Considerações finais}

A vila portuária de Desterro, no quadro oitocentista que estas páginas ansiaram despertar, tinha como destacada presença em trânsito no porto e nas ruas suas mercadorias a se exportar ou importar. Farinha, bebidas, mantimentos, metros de fazendas coloridas. Mas, além da visão

${ }^{29}$ ACMF. Registro de Batismo de Livres da Freguesia do Desterro (1850-1858). 02/março/1851.

${ }^{30}$ ACMF. Registro de Batismo de Livres da Freguesia do Desterro (1850-1858). 05/outubro/1851. 
comercial à época, Desterro era palco de atuação de milhares de vidas. Incontáveis personagens exercendo suas vivências no contexto diaspórico citadino. Homens e mulheres de origens africanas em um teatro de sombras e luzes. Sem ensaios nem roteiros, apenas vivendo e estabelecendo relações afetivas, familiares ou conflituosas, em uma arena a eles imposta, mas cujas atuações garantem-lhes constantes processos de reinvenção identitária, alterando também, assim, suas sobrevivências desterrenses. Estritamente na segunda metade do século XIX, como pode ser observado por meio da documentação apresentada neste artigo, estes homens e mulheres de nação ao desenvolverem seus trabalhos na cidade acabaram por estabelecer diversos vínculos, harmônicos e desarmônicos, indicadores de possibilidades de escolhas e incertezas, imposições e oportunidades, em suas existências. Protagonistas de suas próprias histórias, cujas imagens possíveis encontram-se, para nós, refletidas em seus estilhaços, remanescentes na documentação investigada.

No final do XIX, mas principalmente nas primeiras décadas do XX, a sociedade via-se em rumos cada vez mais mutáveis. A mentalidade dos homens e mulheres das classes burguesas e elitizadas ansiava pela modernidade. Reformas arquitetônicas se erigiam a cada tilintar das picaretas sob os antigos monumentos da época, e os espaços pobres eram, a cada ano que se passava, vistos como borrões em uma tela pintada à moldura parisiense colocada às capitais brasileiras. Os anos caminhavam para a transição monarquia-república e Desterro ainda tinha sobressalentes sobre si choupanas e casinhas alugadas, em contraposição ao progresso com suas garras de ferro e concreto. Diante disto, as elites e classes em ascensão voltam seus poderes às populações pobres, numa tentativa de implementar seus poderes e interesses através de usos institucionais, desta vez com vistorias diretamente acerca de suas habitações. "Nas últimas décadas do século XIX, o Estado passa a intervir no espaço urbano de Florianópolis através da legislação. Em 1880, foi elaborado o primeiro Código de Posturas, que visava regulamentar as atividades urbanas e frear a multiplicação dos cortiços nas áreas centrais" (SOUZA, 2010, p. 31. Grifo nosso).

Sob o controle legislativo, restaria aos pobres dos cortiços e habitações populares, muitíssimos destes homens e mulheres de origem africana, permanências de um passado escravista e colonial, procurar novas alternativas de sobrevivência driblando o processo modernizador florianopolitano que engolia cada vez mais os primeiros anos do século XX. O exorcismo à imagem não saneada da cidade seria consumado com demolições das choupanas e casinhas de aluguel à sombra da luz modernizante que raiava a Capital. Quem as habitava via-se sem condições de pagar as habitações disponíveis na cidade remodelada sob o novo sistema urbano, e a alternativa mais viável à expulsão metropolitana era migrar para as zonas periféricas ao centro. Povoar os inabitados morros às margens da pretensa civilização. Marcá-los como os 
novos "territórios negros" (CARDOSO e MORTARI, 1999) do contexto citadino. Evitáveis. Escapáveis. Invisíveis. Efeitos posteriores ao período analisado neste artigo, mas cujo despertar já se manifestava desde as primeiras implementações dos dispositivos de controle das populações africanas enquanto sombras da hegemonia citadina da elite. Mas isso é outra história...

\section{REFERÊNCIAS BIBLIOGRÁFICAS}

APPIAH, Kwame Anthony. Na Casa De Meu Pai. A África na Filosofia da Cultura. Rio de Janeiro: Contraponto, 1997.

AZEVEDO, Célia Maria Marinho de. Onda Negra, Medo Branco. O negro no imaginário das elites século XIX. Rio de Janeiro: Paz e Terra, 1987.

BENJAMIN, Walter. Sobre o Conceito de História. IN: __. Obras completas. São Paulo: Brasiliense, 1985, p. 224.

CABRAL, Oswaldo Rodrigues. Nossa Senhora do Desterro: notícias, vol. I. Florianópolis: Imprensa da Universidade Federal de Santa Catarina, 1971.

CARDOSO, Paulino de Jesus Francisco Cardoso. Negros em Desterro: Experiências de populações de origem africana em Florianópolis na segunda metade do século XIX. Casa Aberta: Itajaí, 2008.

CARDOSO, Paulino de Jesus Francisco e MORTARI, Claudia. Territórios negros em Florianópolis no século XX. In: BRANCHER, Ana (org). História de Santa Catarina: Estudos Contemporâneos. Florianópolis: Letras Contemporâneas, 1999.

CHALHOUB, Sidney. Diálogos políticos em Machado de Assis. IN: CHALHOUB, Sidney e PEREIRA, Leonardo Afonso de M. (org.). A História Contada. Rio de Janeiro: Nova Fronteira, 1998, p. 95-122.

CHALHOUB, Sidney. O Medo Branco de Almas Negras: Escravos, Libertos e Republicanos na Cidade do Rio. Revista Brasileira de História, São Paulo, v. 8, n. 16. mar./ago. 1988.

CHALHOUB, Sidney. Visões da liberdade. Uma história das últimas décadas da escravidão na Corte. São Paulo: Companhia das Letras, 1990. 
DIAS, Maria Odila Leite da Silva. Quotidiano e poder em São Paulo no século XIX. São Paulo: Brasiliense, 1995.

GEERTZ, Clifford. A Interpretação das Culturas. Rio de Janeiro: Editora LTC, 1989.

GINZBURG, C. Relações de força: História, retórica e prova. São Paulo: Companhia das Letras, 2002.

GINZBURG, Carlo. Mitos, Emblemas e Sinais. São Paulo: Companhia das Letras, 1989.

GOMES, Flávio e SOARES, Carlos Eugênio Libânio. Com o pé sobre um vulcão: africanos minas, identidades e a repressão antiafricana no Rio de janeiro (1830-1840). Estudos AfroAsiáticos. V. 23, n. ${ }^{\circ}$ 2, Rio de Janeiro, 2001.

GOUVÊA, Maria de Fátima Silva. O Antigo Regime nos trópicos: a dinâmica imperial portuguesa (séculos XVI-XVIII). Rio de Janeiro: Civilização Brasileira, 2001.

HALL, Stuart. Da diáspora: identidades e mediações culturais. Belo Horizonte: Editora UFMG, 2003.

HALL, Stuart. Identidade cultural na pós-modernidade. 10 ed., Rio de Janeiro: DP\&A, 2005.

HERNANDEZ, Leila Leite. O Olhar imperial e a invenção da África. In: A África na sala de aula: visita a história contemporânea. Belo Horizonte: Selo Negro, 2005, pp. 17-44.

HÜBENER, Laura M. História Econômica e Financeira. In: MELO, Osvaldo Ferreira de (org). História Sócio-Cultural de Florianópolis. Florianópolis: Clube Doze de Agosto: IHGSC. Lunardelli, 1991.

LEITE, Fábio Rubens da Rocha. A Questão Ancestral. Notas Sobre Ancestrais e Instituições Ancestrais em Sociedades Africanas Ioruba, Agni e Senufo. Tese de Doutorado - USP. São Paulo, 1982.

LEITE, Ilka Boaventura. Descendentes de africano em Santa Catarina: invisibilidade histórica e segregação. In: LEITE, Ilka Boaventura (org). Negros no Sul do Brasil. Ilha de Santa Catarina: Letras Contemporâneas, 1996.

MALAVOTA, Claudia Mortari. Os africanos de uma Vila Portuária no Sul do Brasil: criando vínculos parentais e reinventando identidades. Tese de doutorado, PUCRS, 2007. 
MALAVOTA, Claudia Mortari. Os Homens Pretos do Desterro. Um estudo sobre a Irmandade de Nossa Senhora do Rosário (1841 - 1860). Casa Aberta: Itajaí, 2011.

MAMIGONIAN, Beatriz Galloti. Do que o "preto mina" é capaz: etnia e resistência entre africanos livres. Revista Afro-Ásia, 24 (2000), p. 71-95.

MAMIGONIAN, Beatriz, Gallotti. Africanos em Santa Catarina: escravidão e identidade étnica. In: FRAGOSO, João ... [et al], (orgs.). Nas rotas do Império: eixos mercantis, tráfico e relações sociais no mundo português. Vitória: Edufes; Lisboa: IICT, 2006, p. 609 - 644.

MATTOS, Hebe Maria. A escravidão moderna nos quadros do Império português: o Antigo Regime em perspectiva atlântica. In: FRAGOSO, João, BICALHO, Maria Fernanda Baptista, MATTOS, Regiane Augusto. História e cultura afro-brasileira. 2. ed. São Pauulo: Contexto. 2011.

MENDONÇA, Joceli Maria N. Entre a Mão e os Anéis. Campinas: Editora da unicamp/CECULT, 1999.

OLIVEIRA, Maria Inês Côrtes de. Quem eram os "Negros da Guiné"? A origem dos africanos na Bahia. Afro-Ásia, 19/20 (1997), 37-73.

OLIVEIRA, Maria Inês Cortes. Viver e morrer no meio dos seus. Nações e comunidades africanas na Bahia do século XIX. Revista USP, São Paulo (28), Dez./Fev. 95/96.

PEDRO, Joana Maria. Mulheres Honestas e Mulheres Faladas: Uma Questão de Classe. Florianópolis: UFSC, 1994.

PENA, Eduardo Spiller, Escravos, libertos e imigrantes: fragmentos da transição em Curitiba na segunda metade do século XIX. In: História: questões e debates, Curitiba, 9(16), 1988 p. 83103.

SANTOS, André Luiz. Do Mar ao Morro: a geografia histórica da pobreza urbana em Florianópolis. Florianópolis, 2009. Tese (Doutorado em Geografia). Universidade Federal de Santa Catarina.

SOARES, Marisa de Carvalho. Devotos da cor. Identidade étnica, religiosidade e escravidão no Rio de Janeiro, século XVIII. Rio de Janeiro: Civilização Brasileira, 2000.

SOARES, Marisa de Carvalho. Identidade étnica, religiosidade e escravidão. Os "pretos minas" no Rio de Janeiro (século XVIII). Niterói, UFF, 1997. Tese de doutoramento. 
SOARES, Mariza de Carvalho. Mina, Angola e Guiné: nomes d' África no Rio de Janeiro setecentista. Revista Tempo, v.3, n. 6, Dezembro de 1998.

VEIGA, Eliane Veras da. Florianópolis, Memória Urbana. Florianópolis: Editora da UFSC e FCC, 1993.

XAVIER, Regina C. A Conquista da Liberdade: Libertos em Campinas na segunda metade do século XIX. Campinas: CMU/Unicamp, 1996. 